IRSH 55 (2010), Supplement, pp. I03-I 2 I doi:I0.1017/So020859010000519 (C) 2010 Internationaal Instituut voor Sociale Geschiedenis

\title{
The Colonial Famine Plot: Slavery, Free Trade, and Empire in the French Atlantic, I763-179I*
}

\author{
JOSEPH HORAN \\ Department of History, Florida State University
}

E-mail: jwho4h@fsu.edu

Summary: This essay examines the use of famine-plot rhetoric in the course of disputes over free trade in the French Atlantic during the late eighteenth century. Seeking to discredit officially sanctioned trade monopolies, French plantation owners frequently suggested that the control exercised by metropolitan merchants over transatlantic commerce was responsible for food shortages among the enslaved population of the colonies. In reality, the planters themselves bore primary responsibility for malnutrition in the French Caribbean, thanks to their reliance on the slave trade and support for the expansion of plantation agriculture. While proponents of the colonial famine plot accepted that plantation slavery had made it impossible for the resources available in the colonies to sustain the growing enslaved population, they remained committed to the plantation system. In advocating expanded free trade as the best means to ensure the continued growth of the colonies, French planters anticipated a response to the environmental problems caused by colonial expansion that became increasingly prevalent among proponents of European imperialism during the nineteenth century.

On 29 August 1789 Nicholas-Robert de Cocherel warned his fellow deputies in the French National Assembly that the Caribbean colony of Saint-Domingue, which he represented in the Assembly by virtue of his ownership of several lucrative sugar plantations, "is currently devastated by the most cruel of plagues, that of FAMINE". According to Cocherel, the root cause of this famine was not the encouragement that he and his fellow planters had given to the Atlantic slave trade, which had transported more than a million enslaved Africans to the French colonies over the course of the eighteenth century. Nor could the famine be attributed to their reliance on plantation monoculture, which had seriously weakened the ability of the colonies to sustain their population through local

\footnotetext{
* The author would like to thank Darrin M. McMahon and Frederick Davis for reading and commenting on earlier drafts of this article.
} 
food production. ${ }^{\mathrm{I}}$ Drawing on a brand of rhetoric that Caribbean planters had been developing for several decades, Cocherel instead asserted that the ultimate cause of famine in the colonies was deliberate manipulation of the colonial trade by French merchants. ${ }^{2}$

Since the I760s, wealthy planters such as Cocherel had been using their political influence to spread similar accusations as part of their campaign to bring an end to the exclusive trading privileges enjoyed by the leading merchants of France's major port cities. In order to encourage a relaxation of commercial restrictions, they suggested that the trade monopolies allowed metropolitan merchants deliberately to starve the colonies of basic necessities in order to drive up prices and increase their own profits. This assertion also conveniently offered the planters an opportunity of denying their own basic responsibility for starvation in the colonies.

The rhetoric adopted by Cocherel and his fellow planters during the late eighteenth century closely mirrors the "famine-plot" phenomenon described by historian Steven L. Kaplan. Examining popular reactions to the numerous food shortages and famines that affected metropolitan France over the course of the eighteenth century, Kaplan identified a widespread tendency to blame deliberate manipulation by greedy merchants, speculators, and officials. As Kaplan has demonstrated, the famine-plot phenomenon was a natural product of conditions in eighteenth-century France. For a population that was dependent on the cereal economy, secretive conspiracies seemed to be a logical explanation for periodic food shortages, a tendency that was encouraged by the general lack of transparency in the political system of the ancien régime. ${ }^{3}$

I. The history of slavery in the French Caribbean is the subject of an extensive and growing body of research. For some useful general overviews, see Gabriel Debien, Les Esclaves aux Antilles françaises, XVII-XVIII siècles (Basse-Terre, 1974); Robert Louis Stein, The French Slave Trade in the Eighteenth Century: An Old Regime Business (Madison, WI, 1979); Pierre Pluchon, "L'Économie d'habitation a Saint-Domingue", Revue d'Histoire Maritime, I (1997), pp. 198-241; David Geggus, "The French Slave Trade: An Overview", William and Mary Quarterly, 58 (200I), pp. I I9-I38; and Frédéric Régent, La France et ses esclaves: De la colonisation aux abolitions (I620-I848) (Paris, 2007).

2. Nicholas-Robert de Cocherel, Motion de M. de Cocherel, député de S.Domingue, à la séance du samedi 29 août I789, au soir (Versailles, I789), p. I. All translations are by the author unless otherwise noted.

3. Steven L. Kaplan, "The Famine Plot Persuasion in Eighteenth-Century France", Transactions of the American Philosophical Society, 72:3 (1982), pp. I-79. Historians of early modern France have agreed with Kaplan on the extent to which conspiracy theories permeated political culture. See particularly Arlette Farge and Jacques Revel, The Vanishing Children of Paris, Claudia Milleville (trans.) (Cambridge, I99I); and Peter R. Campbell, "Perceptions of Conspiracy on the Eve of the French Revolution", in Peter R. Campbell, Thomas E. Kaiser, and Marisa Linton (eds), Conspiracy in the French Revolution (Manchester [etc.], 2007). It is also important to recognize that conspiracy rhetoric was by no means a monopoly of the political 
Similar conditions encouraged the use of famine-plot rhetoric in the context of France's Atlantic empire, in which the dissemination of accurate information was further handicapped by the vast distance between France and the colonies. ${ }^{4}$ While traces of famine-plot rhetoric can be found in travel accounts and government correspondence throughout the history of French colonization during the ancien régime, the most explicit version of the "colonial famine plot" revolved around the efforts of leading planters to end the trade restrictions that had been imposed on the colonies. In order to achieve this goal, planters cynically used the suffering of their enslaved laborers as a means of discrediting the commercial privileges enjoyed by metropolitan merchants.

While proponents of the colonial famine-plot persuasion asserted that the immediate cause of starvation in the colonies was the deliberate manipulation of transatlantic commerce by metropolitan merchants, their rhetoric also addressed the broader issues of commercial policy, colonial expansion, and environmental degradation. In this sense, the planters were reacting to a common trend in the history of European imperialism.

As new colonies were incorporated into a global economy that was dominated by European powers, traditional methods of preventing food shortages in these regions were put under increasing strain. The impacts of this trend were particularly devastating in the late nineteenth century, as the incorporation of large parts of Asia and Africa into the European empires produced a series of horrific famines. Supporters of the imperial project, however, viewed these famines not as a product of the policies that they had adopted, but rather as an excuse to further advance the process of incorporating these regions into imperial markets. 5 The rhetoric of the colonial famine-plot provides an early example of this phenomenon. While the planters asserted that it was impossible to nourish the enslaved population of the colonies without foreign commerce, they did not question the plantation system which was responsible for this development. Indeed, their primary goal in advocating free trade was to ensure the continued expansion of the plantation regime.

left. See Darrin M. McMahon, Enemies of the Enlightenment: The French Counter-Enlightenment and the Making of Modernity (Oxford [etc.], 200I), pp. 57-65.

4. Kenneth Banks, Chasing Empire Across the Sea: Communications and the State in the French Atlantic, $1713-1763$ (Montreal [etc.], 2006).

5. For treatments of famine in the historical context of European imperialism, see Amartya Sen, Poverty and Famines: An Essay on Entitlement and Deprivation (Oxford, 1981), pp. 52-85; David Arnold, Famine: Social Crisis and Historical Change (Oxford [etc.], I988), pp. I 19-1 42; William Crossgrove et al., "Colonialism, International Trade, and the Nation-State", in Lucile F. Newman et al. (eds), Hunger in History: Food Shortage, Poverty, and Deprivation (Cambridge [etc.], I990), pp. 2 I 5-240; Mike Davis, Late Victorian Holocausts: El Niño Famines and the Making of the Third World (London [etc.], 200I). 


\section{COMMERCIAL REFORM AND THE COLONIAL FAMINE PLOT, 1763-1789}

During the eighteenth century, the French plantation colonies were supplied through an extensive transatlantic commerce, which provided a wide range of commodities to the Caribbean, including flour from France, cod from the Atlantic fisheries, and even salted beef from Ireland. ${ }^{6}$ Although these products were a significant source of nutrition for both European colonists and enslaved Africans, a mercantilist policy, known as the exclusif, strictly limited their commerce to the merchants of France's major port cities. As the plantation regime expanded over the course of the eighteenth century, these prohibitions became increasingly problematic.

Many planters felt that their needs would be better fulfilled by opening the colonies to foreign commerce, thus legalizing the profitable illicit trade with British and Dutch merchants in which they were already engaged. In the aftermath of the Seven Years' War (1756-1763), the Ministry of the Navy, which was responsible for colonial affairs under the ancien régime, initiated a program designed to reform the exclusif. Under the influence of Jean-Baptiste Dubuc, a wealthy absentee sugar planter from Martinique, in 1767 a policy known as exclusif mitigé was introduced, permitting a restricted foreign trade in certain subsidiary goods such as lumber and live animals. In order to prevent a more general breakdown of trade restrictions, this commerce was limited to two secondary ports, Carénage in the colony of Saint Lucia and Môle SaintNicholas in Saint-Domingue. ${ }^{7}$

Wealthy plantation owners in France and the Caribbean were unsatisfied with this limited reform. During the war, planters in the Caribbean had gained a new voice in colonial politics with the creation of special Chambers of Agriculture in the main colonies of Martinique, Guadeloupe, and SaintDomingue. Initially created to rally colonial support for the war effort, these institutions quickly became a vehicle through which the most influential planters sought to shape colonial policy in their favor. During the $1760 \mathrm{~s}$ planters in the Chambers consistently called for a further relaxation of the exclusif, demanding that all the major ports be opened to foreign commerce in more vital goods such as flour, cod, and salted beef.

6. Bertie Mandelblatt, "A Transatlantic Commodity: Irish Salt Beef in the French Atlantic World”, The History Workshop Journal, 63 (2007), pp. I 8-47.

7. The most comprehensive study of the debates over colonial trade reform in late eighteenthcentury France remains Jean Tarrade, Le commerce colonial de la France à la fin de l'Ancien Régime: l'évolution du régime de "l'Exclusif" de 1763 à 1789,2 vols (Paris, 1972). This summary is drawn from vol. I, pp. 223-338. For the two central decrees of the exclusif system, which dated from I717 and 1727, see Recueils de Règlements, Édits, Déclarations et Arrêts Concernant le Commerce, l'Administration de la Justice, E la Police des Colonies Françaises de l'Amérique, E les Engagés avec le Code Noir et l'Addition audit Code (Paris, 1765), pp. 46-61, 221-238. 
It was during this period that the Chambers of Agriculture began to attack French merchants, whom they accused of deliberately manipulating commercial policy in order to maintain their exclusive privileges. In 1784 , sensitive to this pressure and hoping to encourage closer commercial ties with the newly independent United States, the administration issued a decree permitting the importation of an expanded number of foreign goods, including cod and salted beef, into the leading ports of the French colonies. This decree provoked an intense reaction from French merchants, who launched a propaganda campaign arguing that reform of the exclusif would throw the French economy into a crisis. In a series of pamphlets, the planter lobbyist Dubuc engaged in a heated polemic with the merchants, defending the reforms and calling for a further relaxation of the exclusif. ${ }^{8}$

The dispute over the exclusif reached a peak during the first year of the French Revolution. Absentee sugar planters in Paris had managed to obtain representation in the newly created National Assembly, and they used this platform to campaign for further commercial reform. In the heated political atmosphere of 1789 , the planters significantly expanded on their version of the famine plot, a tendency that was further encouraged by fears that the bad harvest in France would affect food supplies in the French colonies. ${ }^{9}$ In the late summer, reports from the governor of Saint-Domingue, the largest and most populated colony in the Caribbean, suggested that the island was on the verge of famine. When the Minister of the Navy refused their demands for an extended suspension of the exclusif in order to permit the importation of foodstuffs from the United States, the colonial representatives brought the issue to the Assembly, explicitly accusing the merchants of corrupting the political process. ${ }^{\circ}$ These accusations became even more heated when a special committee appointed to examine the matter determined that the claims of famine were greatly exaggerated.

By early $\mathrm{I} 790$, the debates over colonial trade policy had reached a stalemate. While the merchants had successfully blocked the demands of the colonial deputies for a definitive end to the official trade monopolies, the increasing weakness of the administration made it impossible for the

8. Tarrade, Le commerce colonial de la France, II, pp. 493-589.

9. On conspiracy rhetoric during the early years of the Revolution, see Timothy Tackett, "Conspiracy Obsession in a Time of Revolution: French Elites and the Origins of the Terror, 1789-1792", The American Historical Review, I05 (2000), pp. 691-713.

I०. For the reports of the Saint-Domingue administrators concerning the food supply, see MarieCharles, marquis de Chilleau et al., Correspondance de M. le Marquis du Chilleau, GouverneurGénéral de Saint-Domingue, avec M. le Comte de la Luzerne, Ministre de la Marine, E M. de Marbois, Intendant de Saint-Domingue, relativement à l'introduction des farines étrangères dans cette colonie (Paris, I789). On the efforts of the deputies to draw attention to the crisis, see LouisMarthe de Gouy d'Arsy, Première dénonciation solennelle d'un ministre, faite à l'Assemblée nationale, en la personne du Comte de La Luzerne, ministre d'état, de la marine, et des colonies; Extrait des pièces justificatives à l'appui de la dénonciation (Paris, I790). 
French state to exercise even the limited control of the colonial economy associated with the ancien régime. This left the colonists free to ignore trade restrictions more or less. In the years that followed, the issue of colonial trade reform was overshadowed by the more pressing concerns of foreign war and slave insurrection in the colonies. ${ }^{\mathrm{II}}$

The extensive use of famine-plot rhetoric in the French debates over colonial trade was not mirrored in the histories of the other European powers with plantation colonies in the Caribbean. Although the British colonies experienced shortages comparable to their French counterparts in the late eighteenth century, British planters managed to exercise a strong influence on colonial policy. ${ }^{\mathrm{I}}$ French colonial politics, on the other hand, reflected the general lack of transparency that encouraged the famine-plot persuasion during the ancien régime.

While wealthy absentee planters such as Dubuc enjoyed some influence on major decisions affecting the colonies, in the final analysis colonial affairs were the sole responsibility of the Minister of the Navy. Although the policy of the exclusif mitigé reflected the efforts of the successive ministers to balance the interests of the various merchants and planters, the end result satisfied neither party and produced the polemics in which the colonial famine plot was given its fullest expression. While the political culture of the ancien régime influenced the use of famine-plot rhetoric by French planters, their efforts to reform colonial trade policy can be understood only in the context of conditions particular to the colonies. In order to explain fully the development of the colonial famine-plot persuasion, it is necessary to examine the interaction between plantation monoculture, malnutrition, and transatlantic commerce in the French Caribbean.

\section{MALNUTRITION AND THE PLANTATION SYSTEM IN THE FRENCH CARIBBEAN}

The expansion of plantation agriculture in the European colonies of the Caribbean during the seventeenth and eighteenth centuries had a significant

I I. Jean Tarrade, "Le Révolution et le Commerce Colonial: le Régime de l’Exclusif de I789 à I 800", in CHEFF (eds), Etat, Finances et Economie Pendant la Révolution Française (Paris, I99I). For a concise assessment of the crisis in the French Caribbean during the revolutionary and Napoleonic eras, see David Patrick Geggus, "Slavery, War, and Revolution in the Greater Caribbean, I789-18 Is", in David Barry Gaspar and David Patrick Geggus (eds), A Turbulent Time: The French Revolution and the Greater Caribbean (Bloomington, IN, I997), pp. I-50. I 2. On the more permissive trade policies in the Dutch Caribbean, which served as an inspiration for the reforms of the exclusif mitigé, see Wim Klooster, Illicit Riches: Dutch Trade in the Caribbean, I648-I795 (Leiden, 1998). On the subsistence crisis in the British colonies, see Richard B. Sheridan, "The Crisis of Slave Subsistence in the British West Indies during and after the American Revolution", The William and Mary Quarterly, 33 (I976), pp. 6i s-64 I. On the political influence of the British planters, see David Beck Ryden, West Indian Slavery and British Abolition, $1783-1807$ (Cambridge [etc.], 2009), pp. 40-82. 
impact on local environments. Prior to the arrival of European colonists, the fertile soils and biological diversity of these islands supported an agricultural system that generally provided an adequate and balanced diet for the indigenous populations.

Following the initial colonization of the islands during the seventeenth century, the introduction of sugar cane, coffee, and other luxury crops destined for European consumers encouraged a system of intensive settlement and plantation monoculture that exhausted soils and depleted local flora and fauna throughout much of the region. This ecological transformation played a direct role in the problems of food supply experienced in the colonies during the colonial era. ${ }^{13}$ While food production did not cease altogether, it was increasingly inadequate to support the growing population of enslaved laborers transported to the colonies through the Atlantic slave trade. Historians have shown that malnutrition and the wide range of health problems associated with it were endemic among plantation slaves in the Caribbean, and were a leading cause of high rates of slave mortality in the colonies. ${ }^{14}$ Although the famine-plot rhetoric articulated by French planters was part of a self-serving political strategy, there is no denying that starvation was a very real problem for their enslaved laborers.

The environmental degradation caused by plantation monoculture was not lost on contemporary observers. In 1790, the French doctor and agronomist Jacques-François Dutrône de la Couture surveyed the state of agriculture in Saint-Domingue. In virtually every part of the colony, he found signs that the expansion of plantation agriculture, and particularly the rapid extension of coffee planting in recent decades, had seriously damaged the ecosystem. Describing the northern plains of the colony, which were by many accounts the richest and most productive area in the French plantation colonies, Dutrône lamented that, "it is to the activity of the cultivator that we owe the stunning prosperity of the region $[\ldots]$ and it is unfortunate that the cause of this stunning prosperity must also necessarily be that of its wastage and ruin". ${ }^{\text {Is }}$ Nonetheless, Dutrône was revealingly focused only on the production of luxury crops, and showed

I 3. David Watts, "Cycles of Famine in Islands of Plenty: The Case of the Colonial West Indies in the Pre-Emancipation Period", in Bruce Currey and Graeme Hugo (eds), Famine as a Geographical Phenomenon (Dordrecht [etc.], 1984), pp. 49-70.

I4. Frantz Tardo-Dino calculates that, at the very best, the average caloric value of slave diets was sufficient for four days of the week. See his Le Collier de Servitude: La condition sanitaire des esclaves aux Antilles Françaises du XVIIe au XIXe siècle (Paris, 1985), pp. I29-I42. For a detailed assessment of slave malnutrition in the Caribbean as a whole, see Kenneth F. Kiple, The Caribbean Slave: A Biological History (Cambridge [etc.], 1984).

I 5 . Jacques-François Dutrône de la Couture, Précis sur la canne et sur les moyens d'en extraire le sel essential (Paris, 1790), p. 343. On contemporary attitudes to environmental degradation in a colonial context, see Richard H. Grove, Green Imperialism: Colonial Expansion, Tropical Island Edens and the Origins of Environmentalism, 1600-I860 (Cambridge, MA, 1996), pp. 168-308. 
little concern for the problems of food production. Indeed, he finished his survey by advocating commercial reform as the most effective means of ensuring that more enslaved laborers could be transported to the areas of the colony that remained productive. Dutrône's account illustrates both the extent of the environmental problems caused by plantation agriculture in the Caribbean, and the general neglect of sustainability shown by proponents of the plantation regime.

Significantly, however, contemporary observers who did pay attention to food production described a wide range of provisions that were not only available in the colonies, but were cultivated on the plantations themselves. Perhaps the best such description was provided by S-J. Ducoeurjoly, who had extensive experience managing a plantation in Saint-Domingue at the end of the eighteenth century. In a manual for prospective planters written in 1802 , Ducoeurjoly noted that the Caribbean provided a wide range of potentially nourishing products which were easy to cultivate alongside the more lucrative export crops. If a planter wanted to cultivate sweet potatoes, for example, "in two days one can plant more than enough to last for four months".

Ducoeurjoly's account of plantation provisions also emphasized the existence of multiple safeguards against famine. Yams, for example, "can be conserved from one year to another in the granary: thus when other [foodstuffs] are lacking, one does not fear famine so long as one is wellprovided with these". Manioc (also known as cassava), regarded by both contemporaries and historians as one of the most important sources of nutrition for Caribbean slaves, offered similar advantages (see Figure I). "This is a foodstuff that must not be neglected", he advised, "because once it is first raised, it will continue to grow, require little effort, accommodate itself to the initial terrain, and conserve for three or four years in the ground". Nor, Ducoeurjoly suggested, was it difficult for a planter to raise livestock. Planting corn, he noted, "will nourish the poultry, and fatten the pigs". ${ }^{6}$ This account of the abundance of provisions available on the plantations of the French Caribbean contrasts sharply with the claims advanced by proponents of the colonial famine plot, who suggested that foreign trade was the only effective way to provide adequate nourishment for the colonies.

Ducoeurjoly's account suggested that responsible planters would have little trouble securing adequate rations for their slaves, even during the late eighteenth century when the extension of plantation monoculture had already caused significant damage to local ecosystems. If this was indeed the case, why was malnutrition such a persistent problem in the French Caribbean?

I6. S-J Ducoeurjoly, Manuel des habitants de Saint-Domingue, 2 vols (Paris, I802), II, pp. 70-77. For an assessment of the nature of slave provisioning in the French Caribbean, see Gabriel Debien, "La question des vivres pour les esclaves aux Antilles Françaises", Anuario, I 48 (1972), pp. I3I-I72. 


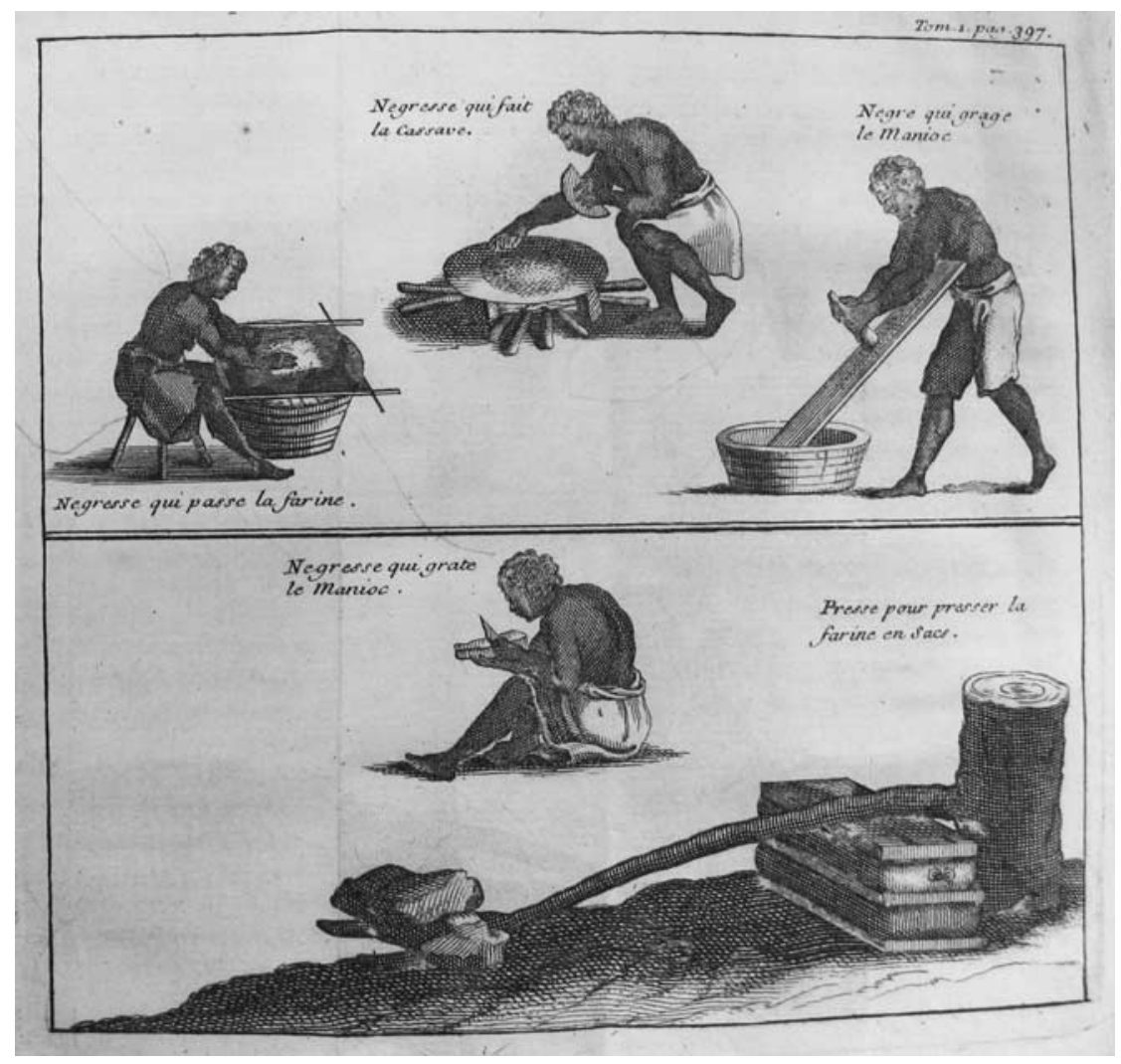

Figure I. Enslaved Africans preparing manioc flour in the French Caribbean during the eighteenth century.

Source: Nouveau Voyage aux isles de l'Amerique, Volume $I$.

FSU Libraries, Special Collections Department. Used with permission.

There are some suggestions that the provisions described by Ducoeurjoly were neither as abundant nor as adequate as his account suggests. The Dominican friar Jean-Baptiste Labat, who visited the Caribbean at the turn of the eighteenth century, suggested that manioc flour was "very expensive, very rare, and very difficult to find". A doctor who visited the island of Saint-Lucia during the 1780 s contended that local crops were "poorly suited to reviving the energy of the organs", and concluded that widespread malnutrition and disease among the slaves were the results of this deficiency. ${ }^{17}$

17. Jean-Baptiste Labat, Nouveau voyage aux isles de l'Amérique: Contenant l'histoire naturelle de ces pays, l'origine, les moeurs la religion et le gouvernement des habitans anciens et modernes. Les guerres et les événements singuliers qui y sont arrivez pendant le séjour que 
Another problem was posed by periodic natural disasters such as hurricanes, earthquakes, and droughts, which could cause significant damage to food crops, creating the conditions necessary for famine. In I776, for example, the Chamber of Agriculture on Martinique issued an urgent plea for help following a series of hurricanes that struck the island. The hurricanes uprooted much of the island's manioc harvest, provoking the inhabitants to engage in a "precipitous consumption" which only exacerbated the shortage. The Chamber lamented the breakdown of social order that followed in the wake of famine, as the population of the colony was driven by hunger to "the most cruel and shameful extremities". ${ }^{8}$

These accounts illustrate some of the difficulties of ensuring adequate food supply that were invoked by proponents of the colonial famine plot as a justification for the introduction of foreign commerce. The most candid observers, however, recognized the real cause of slave malnutrition.

Even proponents of slavery were willing to admit that starvation in the colonies was not caused by a lack of adequate provisions, nor by the restrictions on foreign commerce, but by the plantation system itself. In I 802 , Ducoeurjoly lamented the "condemnable indolence" of many planters, who had neglected to provide proper nourishment to their slaves because they were "dominated by the greed of increasing their profits". This explanation directly contradicted the claims advanced by proponents of the colonial famine plot, who suggested that metropolitan merchants were responsible for starvation in the colonies. As Ducoeurjoly recognized, planters themselves bore the final responsibility for providing adequate nourishment to their slaves, and slave malnutrition could be the result only of planter negligence. Nor were such assessments confined to the period when the development of plantation monoculture was most extensive. Even in the late seventeenth century, when the enslaved population of the colonies was still relatively small, the missionary Jean-Baptiste du Tertre observed that, "as the nutrition of the Blacks depends on their masters, it is very different in every case [...] but to tell the truth, they are all nourished in an entirely pitiful manner". ${ }^{19}$

These admissions reveal the full cynicism of the colonial famine plot. While proponents of free trade in the late eighteenth century suggested

l'auteur y a fait, 8 vols (Paris, I742), III, p. 438; Cassan, "Mémoire sur les cultures de l'isle de Saint-Lucie", in Mémoires d'agriculture, d'économie rurale et domestique (Paris, 1789), pp. 60-66.

I 8. Chambre d'Agriculture de la Martinique, "Mémoire sur la disette actuelle des vivres dans la colonie" (I7 June 1776), Archives Nationales d'Outre Mer, Aix-en Provence [hereafter, ANOM], Series $\mathrm{F}_{-3}$, no. I25. On the impact of hurricanes in other parts of the Caribbean, see Louis A. Pérez, Jr, Winds of Change: Hurricanes and the Transformation of Nineteenth-Century Cuba (Durham, 200I); Matthew Mulcahy, Hurricanes and Society in the British Greater Caribbean, $1624-1783$ (Baltimore, MD, 2006).

19. Ducoeurjoly, Manuel des habitants, pp. 76-77; Jean-Baptiste du Tertre, Histoire générale des Antilles habitées par les Français, 6 vols (Paris, I667), II, p. 5 I3. 
that plantation owners were powerless to provide proper nourishment to their enslaved laborers, the reality was that the authority enjoyed by the master in the plantation system was the primary cause of slave malnutrition.

Further insight into the ultimate responsibility of planters for starvation in the colonies is provided by Labat, whose memoirs described his own experiences as the manager of a sugar plantation in Martinique at the turn of the eighteenth century. According to Labat's calculations, the profits from a well-run sugar plantation were more than sufficient to provide adequate nourishment for the enslaved workers. However, he also emphasized the problems that inevitably arose, problems that were exacerbated by the negligence of many planters. Labat described the various means by which planters sought to minimize the expense of feeding their slaves, such as the distribution of "a certain quantity of rum [eau-de-vie] every week, which takes the place of flour and meat". Labat also denounced planters who, instead of taking direct responsibility for providing adequate rations to their slaves, allowed them one free day per week (typically a Saturday) to cultivate their own gardens. "If the slaves are sick on that day", Labat asked, "or if bad weather prevents them from working, or being lazy and libertine they pass the Saturday without working, what will they eat for the following week?" Planters, Labat emphasized, had an obligation "to furnish to their slaves, whom they should regard as children, everything necessary for their subsistence". ${ }^{20}$

Like many proponents of slavery, Labat viewed the provision of adequate rations as a powerful justification for the authority of the master. However, he was also aware that, in reality, many planters fell well short of this ideal. As observers such as Ducoeurjoly, du Tertre, and Labat recognized, the authority of Caribbean planters over their enslaved workforces, far from providing a solution to issue of food supply, was actually a significant part of the problem.

The Code Noir of 1685 , which theoretically governed the treatment of slaves in the French Caribbean, set a minimum weekly ration, requiring the planters to furnish manioc flour or other Caribbean products, as well as at least two pounds of salted beef or three pounds of salted fish. Given the notoriously widespread disregard of the Code Noir by planters, however, it is likely that even these minimum provisions were rarely provided. Frequent official proclamations calling for more food production in the colonies support contemporary accusations that planters paid little regard to the adequate provisioning of their workforces. In 1776 , for example, the royal administrators of Saint-Domingue issued an ordinance lamenting that "the great majority of Planters in this Colony neglect the plantation and cultivation of manioc, bananas, sweet potatoes, yams, rice, 
and maize, so necessary for the nutrition of many people, and generally for all the Slaves". Such neglect, the administrators noted, contradicted a long list of previous regulations, and could easily cause a catastrophic famine. ${ }^{2 \mathrm{I}}$

The frequency of ordinances like this suggests that the lack of adequate provisions was a persistent problem in the French plantation colonies, in spite of official efforts to encourage local food production. In the final analysis, plantation owners bore the ultimate responsibility for the malnutrition of their enslaved workers. The true "famine plot" in the French colonies was a product of the planters' reliance on the Atlantic slave trade, their encouragement of plantation agriculture, and their negligence of the proper nourishment of the enslaved population.

\section{FAMINE PLOT, FREE TRADE, AND COLONIAL EXPANSION IN THE FRENCH ATLANTIC}

The wealthy planters lobbying for a reform of the exclusif in the late eighteenth century were determined to deny what the most candid observers of slavery in the French Caribbean were willing to admit, that the plantation system was the main cause of starvation in the colonies. In adopting famine-plot rhetoric in the disputes over commercial reform, French planters sought first and foremost to reject their own responsibility for the suffering of their enslaved laborers. To this end, proponents of the colonial famine plot emphasized the lengths to which planters went to provide sustenance for the enslaved population. "Our blacks languish without strength on our plantations, lacking subsistence which we cannot provide to them", the planters sitting in the Guadeloupe Chamber of Agriculture lamented in 1767 . In order to feed their slaves, the planters asserted, the colonists had made "exact searches in all the magazines, and even in the ships in the harbor, without finding a single barrel of beef". ${ }^{22}$

This emphasis on the concern shown by planters for the health of their slaves formed the basis of the colonial famine plot. The conclusion advanced by the planters was that if their efforts to provide for their slaves left nothing to be desired, the only possible explanation for malnutrition was the existence of a deliberate effort on the part of French merchants to starve the colonies of basic necessities.

As criticism of plantation slavery began slowly to penetrate French public opinion at the end of the eighteenth century, plantation owners increasingly used famine-plot rhetoric to defend themselves against

2 I. Méderic-Louis-Élie Moreau de Saint-Méry, Loix et Constitutions des colonies françoises de l'Amérique sous le Vent, 6 vols (Paris, I784-1790), V, p. 729.

22. "Très Humbles Représentations de la Chambre d'Agriculture établie à la Guadeloupe, sur l'arrêt du Conseil d'Etat du Roi du 29 Juillet I767" (24 November 1767), ANOM, Series F-3, no. $\mathrm{I} 26$. 
accusations of cruelty. By blaming food shortages on metropolitan merchants, planters emphasized their own impotence to provide better conditions for their enslaved laborers. According to the colonial lobbyist Dubuc, during times of hardship the conditions of the exclusif made it impossible for planters to feed their slaves, and "the majority of these unfortunates [...] died of hunger, invoking in vain the charity of the Colonists, who had difficulty supplying their own needs". ${ }^{23}$ This assessment was supported by the Chamber of Agriculture of Cap Français, the leading port city of Saint-Domingue, which asserted that in efforts to provide provisions for the enslaved population, "the activity of the planters leaves nothing to be desired". The planters sitting in the Chamber concluded that it was only the influence of French merchants that prevented adequate provisioning.

Critics of slavery, the planters maintained, should direct their complaints against the merchants, "because the enormous depopulation of which they complain, proves the lack of rations that the Colony does not produce, that the Colonist has demanded for sixty years, and that Commerce has had the cruelty to not import". ${ }^{24}$ In 1789 , the planter representatives to the National Assembly insisted that in seeking a relaxation of trade restrictions, they were above all concerned to ensure the happiness of their enslaved workers, insisting that their demands were motivated "more by bumanity than by interest". ${ }^{25}$

The planters offered several explanations as to why the merchants were not supplying the provisions that were so badly needed in the colonies. The most benign interpretation was that French commerce was simply unable to provide the necessary supplies. As early as $\mathrm{I} 76 \mathrm{I}$, the newly created Chamber of Agriculture in Port au Prince lamented the "sterility of national commerce, and the oppositions formed by merchants to neutral commerce". ${ }^{26}$ In 1767 , the planters of Guadeloupe emphasized the

23. [Jean-Baptiste Dubuc and Pierre-Ulrich Dubuisson], Lettres Critiques et Politiques sur les colonies et le commerce des villes maritimes de France, adressées à G-T Raynal (Geneva, I785), pp. I0I-I08. Dubuc advanced similar accusations in another anonymous pamphlet, Le pour et le contre sur un objet de grande discorde et d'importance majeure. Convient-il à l'administration de céder part, ou de ne rien céder aux étrangers dans le commerce de la métropole avec ses colonies? (London, 1784).

24. Mémoire sur le commerce étranger avec les colonies françaises de l'Amérique présenté à la Chambre d'Agriculture du Cap, le 17 février 1784 (Paris, 1785 ), pp. 7-17. Although this memoir is officially dated 17 February 1784 , the explicit reference to the August decree makes it clear that it was composed later.

25. Réponse succinte des Députés de S. Domingue au mémoire des commerçants des ports de mer (Versailles, I789), p. 6, emphasis in original.

26. "Mémoire présenté par les membres de l'Agriculture de la Chambre de Commerce établie au Port-au-Prince, pour exposer au Ministre, ayant le département de la Marine, l'état de cette partie de la colonie de St Domingue" (Is June i76r), ANOM, Series F-3, no. i26. 
inability of French merchants to fulfill their responsibilities to the colonies. "The powerlessness of French commerce in this regard is well-known", they asserted; and "we do not doubt the boldness of their promises, but we have long waited for the effects". ${ }^{27}$

In this view, the main fault of the merchants was clinging to their monopoly over colonial commerce when they were unable to provision the colonies sufficiently. From this basis, however, planters seeking a reform of the exclusif quickly passed to conspiracy theories. By I769, the planters of Guadeloupe had much more specific accusations to make against the merchants of France. The planters complained that in the debates over commercial reform, "several speculators have raised misleading questions, totally foreign to the issue at hand". Even as they demanded expanded permission to trade with foreign merchants, the planters predicted that French merchants would "rise against the propositions that we are advancing, because the private interest that guides them calculates nothing for the group, and accords everything to self-interest" ${ }^{28}$

As the debates over the exclusif intensified in the 1780 , planter lobbyists began to advance more explicit descriptions of the conspiracy that they saw behind efforts to block its further reform. In his polemic against the French merchants, Dubuc described the entire history of the trade restrictions as the product of a deliberate plot. When the policy of the exclusif was first implemented, he claimed, official knowledge of colonial affairs was "surrounded by a thick fog that particular interests had created, and which they took care to maintain". This explanation relied on a common theme of French conspiracy rhetoric, the idea of a well-intentioned monarchy led astray by the powerful influence of greedy conspirators. Dubuc claimed that whenever news of suffering in the colonies reached the French government, the merchants used their influence to deny the existence of food shortages, asserting that the colonists "had everything in the greatest abundance". ${ }^{29}$

The tendency to conspiracy rhetoric became even more pronounced during the Revolution. When a committee created by the National Assembly to examine the claims advanced by the planter representatives concluded that Saint-Domingue was not, in fact, experiencing a famine, the planter deputy Cocherel noted bitterly that four of the six deputies sitting on the committee were merchants. ${ }^{30}$ According to proponents of the colonial famine plot, the Revolution had simply made it easier for the merchants of the port cities to exercise control over colonial policy.

27. “Très Humbles Représentations”, ANOM, Series F-3, no. I 26.

28. "Quelques observations de la Chambre d'Agriculture de la Guadeloupe", ANOM, Series $\mathrm{F}-3$, no. 126 .

29. [Dubuc and Dubuisson], Lettres Critiques et Politiques, pp. IоI-ıо8.

30. Nicholas-Robert de Cocherel, Réflexions de $M$ de Cocherel, député de Saint-Domingue, sur le Rapport du Comité des Six (Paris, I789), pp. I-7. 
In the minds of the planters, the motives behind the colonial famine plot were as devious as the means by which it was carried out. In their assessment, slave malnutrition was a winning proposition for the merchants because they benefited from both the high price of basic necessities and the increased indebtedness of planters whose work gangs had been wiped out. Even as the planters watched "their blacks succumb to misery and famine", Dubuc asserted, "the merchants never ceased to demand the repayment of their debts". ${ }^{1}$ As one Saint-Domingue planter wrote succinctly in 1785 , the ultimate result of the exclusif was to "raise the price of provisions to enrich a few merchants", and he predicted that the end result would be to "kill our poor laborers and ruin their masters". ${ }^{32}$ The planters complained of their subjection to the trade restrictions in a language they knew all too well. In I790, the absentee planter and deputy to the National Assembly Pierre de Thébaudières described trade restrictions as "the shackles that have long made the colonists moan", and asserted that the ultimate goal of the merchants was to "render us more enslaved than our Blacks". ${ }^{33}$

Even as they refused to accept responsibility for starvation in the colonies, proponents of the colonial famine plot demonstrated that they understood the problems caused by their reliance on plantation slavery. In their campaign against the exclusif, planters frequently emphasized that the colonies were simply unable to supply their own needs. In $176 \mathrm{I}$, the Port au Prince Chamber of Agriculture observed that "a country which absolutely lacks that which is necessary for the subsistence of its colonists [...] can only be thrown into violent crisis in seeing itself deprived of constant commerce that can supply all of its needs". ${ }^{34}$

Several years later, the planters of Guadeloupe provided a more detailed discussion of this issue. The planters admitted that when the colony was first founded by a handful of adventurers in the seventeenth century, abundant natural resources had provided for "an easy subsistence". With the arrival of sugar and coffee cultivation at the end of the century, however, "the population began to accumulate rapidly, both from the number of Europeans who transplanted themselves to this country, and from the even greater number of blacks demanded by these new branches of agriculture". With this transformation, the planters noted, "hunting and fishing were exhausted, [and] dried cod became a necessary provision for the blacks and for many of the whites". ${ }^{35}$

31. [Dubuc and Dubuisson], Lettres Critiques et Politiques, pp. IоI-ı०8.

32. "Observations d'un habitant de Saint-Domingue, sur le mémoire des négociants de Bordeaux", ANOM, Series F-3, no. 84 .

33. Pierre-André-François de Thébaudières, Vues générales sur les moyens de concilier l'intérêt du Commerce National avec la prospérité des Colonies (Paris, I790), pp. 6-8.

34. "Mémoire présenté", ANOM, Series F-3, no. I26.

35. "Quelques observations de la Chambre d'Agriculture de la Guadeloupe", ANOM, Series

$\mathrm{F}-3$, no. I26. On the turn-of-the-century environmental transformations described by the 
In 1784 , the Chamber of Agriculture in Cap Français described the nature of agriculture in the colonies, focusing specifically on the choice between the crops needed to feed the colonial population and those destined for export to Europe. "As for vegetables and other provisions", they asserted, "the colony can produce them only in detriment to colonial goods [i.e. sugar and coffee]". The Chamber recognized that the expansion of plantation agriculture threatened the ability of the colonies to supply their own needs. "To the extent that the [luxury] crops have been extended", the planters contended, "the mountains have been degraded, and the resources for provisioning have diminished". The ecological conditions in the colonies, the Chamber suggested, presented planters with a choice between growing enough foodstuffs to feed their enslaved laborers and extending the cultivation of colonial products. In order for the colonies to produce enough food to sustain their population, the planters asserted, "provisions must take the place of coffee, and this precious source of wealth will be lost to France". With these conditions in mind, the planters demanded, "Can you ask the colonist to plant provisions, which are necessarily sold at a low price, in place of the goods that can enrich him?" ${ }^{6}$ This logic accounts for the unwillingness of the colonists to abandon either plantation agriculture or the slave trade, even as they decried the suffering caused by food shortages in the colonies.

On various occasions, the planters advanced exact figures to describe the loss of life that they attributed to the colonial famine plot. Dubuc claimed that the strict application of the exclusif since 1727 had "killed more than fifteen thousand human beings". The planters of Cap Français went much further, calculating that "the lack of rations has cost us a million blacks". Seeking to instill a sense of urgency in his colleagues in the National Assembly, in 1789 the planter deputy Jean-François Reynaud de Villeverde emphasized that, as a result of the trade restrictions, "I0,000 to I 2,000 die of hunger each year". ${ }^{37}$

While these statistics were used to discredit proponents of the exclusif, planters also consistently demanded permission to import even greater numbers of enslaved laborers. According to the Guadeloupe Chamber of Agriculture, French commerce "can supply us only with 3,000 blacks [per year], while replacing [the losses caused by] death and flight requires at least $5,000^{\prime \prime} 3^{8}$

planters, see Philip Boucher, France and the American Tropics to 1700: Tropics of Discontent? (Baltimore, MD, 2008), pp. $235^{-236 .}$

36. Mémoire sur le commerce étranger, pp. $25-28$.

37. [Dubuc and Dubuisson], Lettres Critiques et Politiques, pp. 89-92; Mémoire sur le commerce étranger, pp. I-6; Jean-François Reynaud de Villeverde, Motion de M. le comte de Reynaud, député de Saint-Domingue, a la séance du 3 I Août (Versailles, 1789), pp. I-6.

38. "Quelques observations de la Chambre d'Agriculture de la Guadeloupe", ANOM, Series $\mathrm{F}-3$, no. 126 . 
The Chamber of Agriculture in Cap Français noted pointedly that "the English [slave traders] furnish their blacks at half the price that French merchants demand from the colonists." ${ }^{39}$ While admitting that the colonies were unable to produce sufficient provisions to prevent high rates of mortality, the planters firmly demanded the right to purchase even greater numbers of enslaved laborers.

In order to defend their demands for commercial reform, the planters asserted that opening the colonies to foreign merchants was the only means to ensure the continued expansion of the plantation system. In I768 the planters of Cap Français lamented that the malnourishment of their labor force left them "very far from thinking of clearing new land or the perfection of agriculture". ${ }^{\circ}$ Assessing the state of agriculture in the colony of Saint-Domingue twenty years later, Dubuc estimated that "its production can be augmented by more than a third, perhaps even by half" if the trade monopolies were done away with. Because the exclusif prevented planters from purchasing enough enslaved workers and sustaining those they could obtain, Dubuc argued, "a large portion of the land susceptible to exploitation still waits for cultivators". He also predicted that free trade would permit "more intense cultivation of the existing plantations, which requires improvements that the [current] lack of blacks renders impossible so long as more effective measures are not taken to support their nutrition and replenish the work gangs". ${ }^{4 \mathrm{I}}$ Even as proponents of the colonial famine plot persuasion admitted that plantation monoculture had made it impossible for the colonies to sustain themselves, they anticipated the further expansion of the plantation system promised by commercial reform.

French planters thus presented trade reform as the most effective means to ensure the prosperity of the colonies and the expansion of the French empire. The exclusif, the planters of Guadeloupe maintained, went against "the true interests of the state". ${ }^{2}$ Their counterparts in Cap Français agreed, asserting that "unlimited freedom of foreign commerce is as useful to the aggrandizement of the Colonies as to the prosperity of national Commerce". The planters argued that the basis for establishing successful colonies "consists of the easing of the fate of the slaves", and while they were fully willing to claim credit for the supposedly humanitarian aspects of trade reform, the planters made it clear that their primary purpose in seeking a relaxation of the exclusif was to encourage the further development

39. Mémoire sur le commerce étranger, p. 22.

40. "Mémoire de la Chambre d'Agriculture du Cap" (2 December i768), ANOM, Series F-3, no. 125 .

4I. [Dubuc and Dubuisson], Lettres Critiques et Politiques, p. 83 .

42. "Quelques observations de la Chambre d'Agriculture de la Guadeloupe", ANOM, Series $\mathrm{F}-3$, no. I 26 . 
of the plantation system..$^{43}$ In this way, the colonial famine-plot persuasion constituted a response to the ecological catastrophes induced by European colonization of the Caribbean, but a response premised on the further expansion of the colonial system.

In advancing the cause of commercial reform, French planters suggested that the alternative was nothing less that the ruin of the colonies. As Dubuc explained, "every black with nothing to eat necessarily flees his master's plantation". Eventually, he predicted, "these unfortunates, who have been pushed by hunger and despair", would begin to organize brazen attacks against the plantations. In these circumstances, maintenance of the exclusif posed a grave danger to the security of France's colonies. If not checked, Dubuc claimed, the obstinacy of the merchants in clinging to their trade monopolies "will one day cause the throats of the masters to be slit by their own slaves, after having killed half of those through famine". ${ }^{44}$ On the eve of the Haitian Revolution, the colonial representative Reynaud offered a similar warning to his colleagues in the National Assembly, asserting that "the lack of rations leads to thefts, quarrels, desertions, revolts, and even murders." 45

This assessment reflected the general tendency of eighteenth-century Europeans to attribute slave resistance to outside influences, denying that the slaves on their own might be capable of defying the plantation system. ${ }^{46}$ During the revolutionary crisis of the I790s planters fixed the blame for slave resistance on abolitionist movements, but in the final decades of the ancien régime metropolitan merchants and the exclusif played a similar role for proponents of the colonial famine plot persuasion.

While the influence of the planter lobby in France suffered a sharp decline in the first half of the I790s, by the end of the decade they had again succeeded in infiltrating the halls of power, guiding Napoleon's failed attempt to retake Saint-Domingue, as well as his successful efforts to restore slavery in France's other colonies. ${ }^{47}$ From this perspective, the political activities of wealthy planters at the end of the ancien régime resemble less the death throes of a doomed aristocracy than a foreshadowing of later responses to the problems posed by colonial expansion. In particular, the adoption of famine-plot rhetoric to the campaign for commercial reform reflects a sophisticated, if ultimately self-serving,

43. Mémoire sur le commerce étranger, pp. I-6.

44. [Dubuc and Dubuisson], Lettres Critiques et Politiques, p. I24.

45. Reynaud, Motion de M. le comte de Reynaud, pp. I-6.

46. Michel-Rolph Trouillot, Silencing the Past: Power and the Production of History (Boston, MA, I995), pp. 70-107.

47. On the resurgence of planter influence, see Laurent Dubois, A Colony of Citizens: Revolution E Slave Emancipation in the French Caribbean, $1787-1804$ (Chapel Hill, NC [etc.], 2004), pp. 277-307. 
understanding of the ecological catastrophes that followed in the wake of European colonization and the growth of the plantation system in the Caribbean.

Rather than attempt to moderate the system of monoculture and environmental degradation that they had created, the planters called for free trade as a means of further sustaining the colonial enterprise. In this, their response anticipated that of later proponents of empire, who denied their own basic responsibilities for the devastating famines of the late nineteenth century even as they promoted the further integration of colonized regions into European-dominated global markets. 